P08

Termination of the Gotnia Salt and its Effects on the Petroleum System of the Partitioned Zone, Saudi Arabia and Kuwait

R.A. Corley* (Saudi Arabian Chevron), M. Ye (Chevron Wafra Joint Operations) \& S. Kumar (Kuwait Gulf Oil Company)

For abstract, PTO

No full paper available 


\title{
15276 Termination of the Gotnia Salt and its effects on the petroleum system of the Partitioned Zone, Saudi Arabia and Kuwait
}

\author{
Robert Corley (Saudi Arabian Chevron <corlera@chevron.com>), \\ Mike Ye (Chevron Wafra Joint Operations) and Sukhdarshan Kumar (Kuwait Gulf Oil Company)
}

The Partitioned Zone is an area located along the southern border of the State of Kuwait and the northeastern portion of the Kingdom of Saudi Arabia. The Gotnia Formation of Late Kimmeridgian to Early Tithonian age lies unconformable below Sulaiy/Makhul formations and conformable above the Jubaila Formation, within the Partitioned Zone. Gotnia age-equivalent formations, on the Arabian Platform, include the Arab-Hith formations of Saudi Arabia, Qatar and United Arab Emirates. The Gotnia Formation extends from southern Iraq through Kuwait reaching a maximum thickness of approximately 1,500 feet in southern Kuwait. The termination of the Gotnia Formation is approximately $50 \mathrm{~km}$ south of its recorded maximum thickness. Terminus of the Gotnia Formation is mappable and extends in an east-west direction through the Partitioned Zone. Extensive 3-D and 2-D seismic coverage allows detailed identification of the southern pinch-out of the Gotnia Formation. Subsurface control is also aided by several deep wells on either side of the Gotnia pinch-out. This effort will demonstrate and define the structural and stratigraphic nature of the Gotnia Formation's southern terminus and its effect on the petroleum system within the Partitioned Zone. 